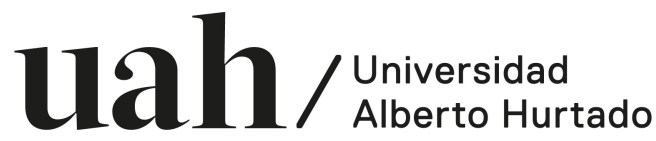

\section{ILADES-UAH Working Papers Series}
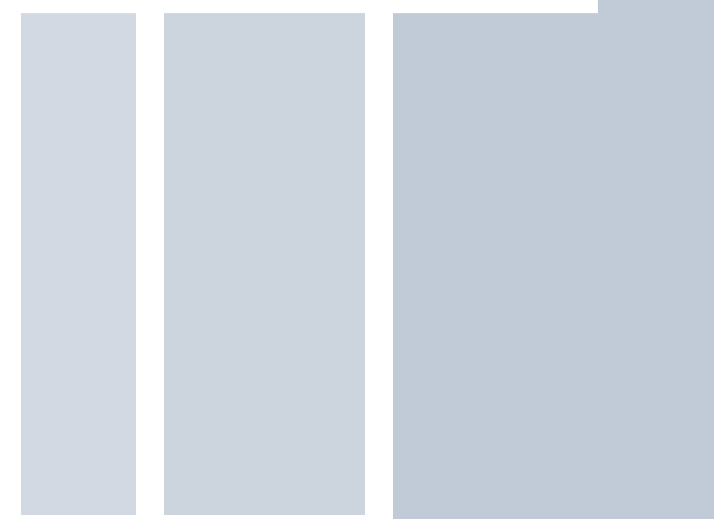

№ $333 / 2019$

Foreign Production and Environment: Does the Type of FDI Matter?

February 2019 


\title{
Foreign Production and Environment: Does the Type of FDI Matter?
}

\author{
Evangelina Dardati*, Meryem Saygili ${ }^{\dagger}$
}

February 11, 2019

\begin{abstract}
We use microdata from Chile to examine the relationship between foreign ownership and the environmental performance of firms. We make a distinction between exporting vs. non-exporting foreign firms. We proxy environmental performance by a measure of emission intensity. We find that foreign firms that serve only the domestic markets have higher emission intensity than foreign exporters.
\end{abstract}

Keywords: Emission intensity, export status, foreign ownership.

JEL classification: F18, Q56.

\section{Introduction}

An extensive trade literature focuses on the motives for multinational production and makes a distinction between horizontal and vertical foreign direct investment (FDI). The proximity concentration hypothesis explains horizontal FDI as being a substitute for exports when trade costs are high. On the other hand, vertical multinationals geographically separate the stages of production primarily to exploit factor price differences across countries. Besides,

*ILADES-Universidad Alberto Hurtado, Department of Economics, Erasmo Escala 1835, Santiago, Chile, email: edardati@uahurtado.cl.

${ }^{\dagger}$ The University of Texas at Tyler, Department of Social Sciences, Economics Division, 3900 University Blvd. Tyler, TX, 75799, email:msaygili@uttyler.edu 
some researchers in the environmental literature argue that when environmental regulations get stricter in developed countries, firms with already strong international linkages can easily relocate their pollution-intensive activities to less regulated countries (Pollution Haven Hypothesis). Linking these pieces from the two literature, we conjecture that if multinational corporations in developed countries offshore dirty products/processes to their subsidiaries in less-regulated countries then foreign-owned firms in developing countries that are vertically linked to their parents would be more emission intensive than foreign-owned firms that only serve local markets.

Our data enable us to track export and foreign ownership status of firms over years. We have four possible combinations: domestic plants that only serve domestic markets, domestic exporters, foreign non-exporters, and foreign exporters. We refer to non-exporting but foreign-owned plants as Horizontal FDI (Local market oriented FDI). However, we avoid labeling foreign exporters as Vertical FDI since we do not know if these plants are exporting back to their parents or to third parties. ${ }^{1}$ Instead we use call these firms "Export-oriented FDI".

We find that, contrary to our prediction, foreign firms that serve only domestic markets have higher emission intensity than foreign exporters. A close look at the foreign production figures in Chile postulates a possible rationale for our findings. Chile receives FDI from both developed and developing countries. Considering the aforementioned motives for foreign production, if Chile's inward FDI from developing economies has market-seeking motives, whereas FDI from developed countries is more export-oriented, then it is not surprising to see that these export-oriented foreign plants have lower energy intensity. Most of the developed economies already have high environmental standards, and their affiliates in developing economies will outperform local firms or foreign firms from other developing economies.

We are not the first to note that different types of FDI might have different implications for the environment. Rezza (2013) uses disaggregated data on sales by Norwegian multina-

\footnotetext{
${ }^{1}$ In reality, only a small number of firms are strictly vertical or horizontal, while the majority of multionationals engage in complex intengration strageties (Yeaple, 2003; Feinberg and Keane, 2006).
} 
tionals' affiliates from 1999 to 2005, categorizing FDI as either efficiency-seeking (vertical) or market-seeking (horizontal). He finds that the environmental stringency of host countries has a significant negative effect on multinationals with vertical motives. Tang (2015) uses US outward FDI data for 50 host countries between 1999-2003 and finds a significant deterrent effect of local environmental regulations on inward FDI. Similar to Rezza (2013), he finds that export-oriented FDI exhibits greater sensitivity to local environmental regulations than local market-oriented FDI exhibits. Both of these studies test the pollution haven hypothesis (PHH), making a distinction between types of FDI. Our paper does not provide a direct test of the PHH. Instead, we contribute to the literature by looking at plant-level data from a host country and focusing on different types of foreign plants. The effect of foreign ownership on firms' environmental performance has been studied extensively, but we are not aware of a paper that distinguishes between different types of foreign firms.

The next section includes details of our data. Section 3 presents the emprical analysis. Section 4 concludes with a short discussion.

\section{Data}

Our data are from an annual survey of Chilean manufacturing plants with more than ten employees. The dataset covers the years 1995 to 2007 and has information on plant sales, value-added, employment, capital stock, fuel use, as well as export sales and the share of foreign ownership. The data also have industry codes from ISIC Rev.3. We deflate our variables by appropriate price deflators to get real values. We follow Wooldridge (2009)'s two-step estimation procedure with a GMM to estimate firm level total factor productivities (tfp). We exclude the following two industries that depend heavily on natural resources: basic precious and non-ferrous metals, and basic chemicals, except for fertilizers and nitrogen compounds (Kohn et al., 2016). ${ }^{2}$ We use energy intensity as a measure of emission intensity: value of energy input divided by total sales (Both in Chilean Peso $\$ s$ ). We also estimate

\footnotetext{
${ }^{2}$ We get qualitatively similar results if include these industries.
} 
$\mathrm{CO}_{2}$ emissions using emission coefficients for the different types of fuels provided in the data (Forslid et al., 2018; Lyubich et al., 2018). Our second measure of emission intensity is the total estimated $\mathrm{CO}_{2}$ emissions $\left(\mathrm{KCO}_{2}\right)$ divided by sales.

In our analysis we control for a number of plant characteristics. In particular, we define size as the number of total workers; skill intensity as the number of white-collar workers divided by the number of blue-collar workers; and capital intensity as the value of capital stock divided by the wage bill. ${ }^{3}$ Table 1 provides summary statistics of the variables in our analysis.

Our data allows us to identify and follow the export and foreign ownership status of firms over years. We label all firms reporting positive export sales as exporters. We consider any firm for which the share of foreign ownership exceeds $50 \%$ as foreign. Table 2 provides details on export status and foreign ownership. The share of foreign-owned plants is about $4 \%$ while the share of exporters is about $20 \%$. The share of horizontal FDI among all plants is only 1.6\%. They, however, make $39 \%$ of foreign plants. The majority of foreign plants (61\%) are exporters. The share of foreign ownership and export status are pretty stable across years. The former ranges between $3.69 \%$ and $4.47 \%$ while the latter is between $18.13 \%$ and 20.75 $\%^{4}$

Table 3 shows the average values of firm characteristics by type of firms. According to both measures of emission intensity (energy and $\mathrm{CO}_{2}$ intensity), domestic firms are the most emission-intensive while foreign exporters are the least emission-intensive. Domestic exporters seem to outperform non-exporting foreign firms in terms of emissions, skill, and capital-intesity. However, in terms of productivity, foreign exporters are followed by foreign non-exporters, then domestic exporters. The least productive firms are the ones that serve only the domestic market. This sorting pattern is consistent with the findings of the literature (Helpman et al., 2004). The size measures in the last two columns (sales and employment)

\footnotetext{
${ }^{3}$ When we take the ratio of white-collar to blue-collar workers to calculate skill intensity, we add 1 to the denominator since a significant number of plants report zero for the number of blue- or white-collar workers.

${ }^{4}$ We only report the average share of export status and foreign ownership over years. Yearly percentages are available upon request.
} 
indicate that foreign exporters are significantly larger than foreign non-exporters (Horizontal FDI). The FDI literature shows that affiliates created to supply a foreign market as an alternative to exporting are relatively small (Ramondo et al., 2016).

Chile is a relatively open developing economy and a major recipient of FDI. Average inward FDI flow and stock as a percentage of GDP are about $6.2 \%$ and $55 \%$, respectively, in our sample period. The corresponding averages for all developing economies are $2.8 \%$ and $21.7 \%$ (UNCTAD). Table 4 shows the number of affiliates and average sales per affiliates for the countries that have more than ten affiliates in Chile. The data are from Ramondo et

al. (2015) for non-financial sectors averaged over the period 1996-2001. Chile hosts affiliates from both developed and developing countries. The average sales of affiliates from developing countries are notably smaller than those from developed counties.

\section{Emprical Anaylsis}

In order to identify the impact of different types of FDI on the environmental performance firms, we estimate the following empricial model:

$$
z_{i j t}=\beta_{0}+\beta_{1} D E_{i j t}+\beta_{2} H F D I+\beta_{3} E F D I+\beta_{4} X_{i j t}+\alpha_{j}+\gamma_{t}+\epsilon_{i j t}
$$

where $z_{i j t}$ is the emission intensity of plant $i$ in industry $j$ at time $t$. DE, HFDI, and $E F D I$ are dummy variables representing domestic exporters, foreign non-exporters (Horizontal FDI), and foreign exporters (Export-Oriented FDI), respectively. The baseline group includes non-exporting domestic firms. The vector of plant characteristics, $X$, includes tfp, size, capital intensity, and skill intensity. We include 3-digit industry and year dummies in all specifications, and cluster standard errors at the plant level. All independent variables, except for dummies, are in logs.

We $\log$ transform energy intensity but use $\mathrm{CO}_{2}$ intensity in levels since about $20 \%$ of observations are zero. The OLS results in Table 5 show that the coefficients on foreign and domestic exporters are negative and statistically significant, while the coefficient on horizontal FDI is not statistically significant. Among all firms, foreign exporters have, on 
average, the lowest energy and $\mathrm{CO}_{2}$ intensity, followed by domestic exporters. The emission intensities of non-exporting foreign firms are not different from those of domestic firms. This suggests that, on the contrary to our prediction, foreign firms that serve only the domestic market have higher emission intensity than export-oriented foreign firms have.

Although the distribution of $\mathrm{CO}_{2}$ intensity is skewed, we cannot log transform it because of the non-trivial number of zeros. Our sample size is big, and, thus, non-normality should not pose a problem for an OLS analysis. We still estimate Equation 1 via GLM with a log link as a robustness check. The results in Table 6 are similar. Firms in the export-oriented FDI category have smaller $\mathrm{CO}_{2}$ intensity than firms in the horizontal FDI category.

\section{Conclusion}

The PHH predicts that strengthening environmental regulation in a country causes relocation of pollution-intensive activities to countries with less-stringent regulations. In that case, multinational firms with already strong international linkages would find it easier to relocate their polluting activities to less-regulated markets. Our data do not allow us to provide a direct test of the PHH. Instead of directly testing it, we conjecture that if the hypothesis were valid, we would expect foreign firms that serve only local markets to be cleaner than foreign firms that export, as the latter are the potential culprits. Instead, our analysis shows that exporting foreign firms are significantly less emission-intensive than non-exporting foreign firms.

Aggregate multinational production figures from Chile provide some insight. Chile hosts multinationals from both developed and developing countries. If the foreign firms from more-developed economies are export-oriented, while those from developing countries serve mainly the domestic market, then we can posit a possible explanation. Multinationals from developed economies are already exposed to strict environmental laws and hence, presumably have cleaner technologies. We have reason to think that multinationals from developed countries are export-oriented, while those from developing economies are local-market-oriented. 
If we look at the microdata, export-oriented foreign firms are significantly bigger than all other types of firms. If we look at the aggregate data, we see that affiliates from developed countries are significantly bigger.

\section{References}

[1] Feinberg, S.E., and Keane, M.P., "Accounting for the Growth of MNC-Based Trade Using a Structural Model of U.S. MNCs", American Economic Review, (2006), Vol 96(5), 1515-1558.

[2] Forslid, R., Okubo, T., and Ulltveit-Moe, K.H., "Why are firms that export cleaner? International trade, abatement, and environmental emissions", Journal of Environmental Economics and Management, (2018), Vol 91, 166-183.

[3] Helpman, E., Melitz, M.J., and Yeaple, S.R., "Export versus FDI with Heteregeneous Firms", American Economic Review, (2004), Vol 94(1), 300-316.

[4] Kohn, D., Leibovici, F., and Szkup, M. "Financial frictions and new exporter dynamics", International Economic Review, (2016), Vol 57(2), 453-486.

[5] Lyubich, E., Shapiro, J.S., and Walker, R. "Regulating mismeasured pollution: Implications of firm heterogeneity for environmental policy", (2018), NBER Working Paper 24228.

[6] Ramondo, N., Rodriguez-Claire, A., and Tintelnot, F., "Multinational Production: Data and Stylized Facts", American Economic Review, Papers and Proceeding, (2015), Vol 105(5), 530-36.

[7] Ramondo, N., Rappoport, V., and Ruhl, K.J., "Intrafirm Trade and Vertical Fragmentation in U.S. Multinational Corporations", Journal of International Economics, (2016), Vol 98, 51-59. 
[8] Rezza, A.A., "FDI and pollution havens: Evidence from the Norwegian manufacturing sector", Ecological Economics, (2013), Vol (90), 140-149.

[9] Tang, J., "Testing the Pollution Haven Effect: Does the Type of FDI Matter?", Environmental and Resource Economics, (2015), Vol 60(4), 549-578.

[10] Yeaple, S.R., "T he complex integration strategies of multinationals and cross country dependencies in the structure of foreign direct investment", Journal of International Economics, (2003), Vol 60, 293-314.

[11] Wooldridge, J.M., "On estimating firm-level production functions using proxy variables to control for unobservables", Economic Letters, (2009), Vol 104, 112-114.

Table 1: Summary Statistics

\begin{tabular}{lccccc}
\hline Variables & mean & $\min$ & $\max$ & $\operatorname{std}$ & $\mathrm{N}$ \\
\hline Energy intensity & .06 & 0 & 295.80 & 1.35 & 64,375 \\
$\mathrm{CO}_{2}$ intensity & .48 & 0 & 988.40 & 6.15 & 64,375 \\
Size & 73.34 & 0 & 5745 & 159.38 & 67,623 \\
Skill intensity & 4.10 & 0 & 3412 & 30.39 & 67,623 \\
Capital intensity & 7.98 & 0 & 12215.47 & 129.174 & 67,579 \\
TFP & 1.99 & -8.38 & 9.44 & 1.23 & 67,185 \\
\hline
\end{tabular}

Energy intensity: energy use/sales, $\mathrm{CO}_{2}$ intensity: estimated $\mathrm{CO}_{2}$ emissions/sales, Size: total workers, Skill intensity: white collar workers/blue collar workers, Capital intensity: capital stock/wage bill, TFP: total factor productivity in logs. 
Table 2: Export Status and Foreign Ownership

\begin{tabular}{lcc|c}
\hline & Foreign & Domestic & Total \\
\hline Exporter & 53,360 & 1,099 & 54,459 \\
& $(78.91)$ & $(1.63)$ & $(80.53)$ \\
Non-exporter & 11,421 & 1,743 & 13,164 \\
& $(16.89)$ & $(2.58)$ & $(19.47)$ \\
\hline Total & 64,781 & 2,842 & 67,623 \\
& $(95.80)$ & $(4.20)$ & $(100.00)$ \\
\hline
\end{tabular}

Frequencies with cell percentages in parentheses.

Table 3: Average firm characteristics by type

\begin{tabular}{lccccccl}
\hline Firm Type & EI & CI & SI & KI & TFP & Emp & Sales \\
\hline Domestic & .066 & .54 & 3.78 & 7.92 & 1.91 & 44 & $1,083,870$ \\
Domestic Exporter & .038 & .30 & 4.78 & 8.72 & 2.26 & 188 & $8,572,800$ \\
Horizontal FDI & .048 & .42 & 4.48 & 5.53 & 2.40 & 101 & $5,514,370$ \\
Export-Oriented FDI & .031 & .25 & 9.49 & 6.65 & 2.55 & 215 & $14,926,942$ \\
\hline Total & .060 & .48 & 4.10 & 7.98 & 1.99 & 159 & $2,777,505$ \\
\hline
\end{tabular}

EI: emission intensity, CI: $\mathrm{CO}_{2}$ intensity, SI: skill intensity, Emp: employment.

Employment and sales are rounded to nearest integers. 
Table 4: Multinational production by source

\begin{tabular}{lcc}
\hline Source & number of affiliates & sales per affiliate \\
\hline URY & 13 & $1,301,566$ \\
FRA & 15 & $1.17 \mathrm{e}+07$ \\
KOR & 18 & $1,509,233$ \\
VEN & 24 & $4,926,670$ \\
NLD & 26 & $1.80 \mathrm{e}+07$ \\
ESP & 28 & $1.06 \mathrm{e}+07$ \\
GBR & 29 & $9,822,546$ \\
CAN & 33 & $1.74 \mathrm{e}+07$ \\
ARG & 47 & $9,093,264$ \\
MEX & 48 & $2,450,858$ \\
GER & 81 & $1.07 \mathrm{e}+07$ \\
USA & 197 & $5.55 \mathrm{e}+07$ \\
\hline
\end{tabular}


Table 5: Effect of Export and Foreign Ownership Status on Plant Emission Intensity

\begin{tabular}{lcccccc}
\hline & \multicolumn{5}{c}{ Energy intensity } & \multicolumn{3}{c}{$C O_{2}$ intensity } \\
\hline DE & $(1)$ & $(2)$ & $(3)$ & $(1)$ & $(2)$ & $(3)$ \\
\hline \multirow{2}{*}{ HFDI } & $-0.125^{* * *}$ & -0.024 & $-0.096^{* * *}$ & $-0.258^{* * *}$ & $-0.208^{* * *}$ & $-0.192^{* * *}$ \\
& $(0.028)$ & $(0.026)$ & $(0.028)$ & $(0.076)$ & $(0.070)$ & $(0.064)$ \\
EFDI & 0.007 & $0.129^{*}$ & $0.113^{* 1}$ & -0.023 & 0.037 & 0.060 \\
& $(0.070)$ & $(0.067)$ & $(0.067)$ & $(0.080)$ & $(0.078)$ & $(0.076)$ \\
TFP & $-0.215^{* * *}$ & -0.069 & $-0.148^{* *}$ & $-0.264^{* * *}$ & $-0.191^{* * *}$ & $-0.216^{* * *}$ \\
& $(0.064)$ & $(0.059)$ & $(0.060)$ & $(0.067)$ & $(0.057)$ & $(0.065)$ \\
Size & & $-0.341^{* * *}$ & $-0.351^{* * *}$ & & $-0.174^{* * *}$ & $-0.167^{* * *}$ \\
& & $(0.013)$ & $(0.013)$ & & $(0.044)$ & $(0.030)$ \\
Skill intensity & & & $0.048^{* * *}$ & & & $0.065^{* *}$ \\
Adjusted R-squared & 0.161 & 0.208 & 0.214 & 0.003 & 0.003 & 0.010 \\
\hline
\end{tabular}

Robust standard errors in parentheses

*** $\mathrm{p}<0.01, * * \mathrm{p}<0.05,{ }^{*} \mathrm{p}<0.1$ 
Table 6: Effect of Export and Foreign Ownership Status on $\mathrm{CO}_{2}$ Intensity: GLM

\begin{tabular}{lccc}
\hline & $(1)$ & $(2)$ & $(3)$ \\
\hline DE & $-0.470^{* * *}$ & $-0.364^{* * *}$ & $-0.427^{* * *}$ \\
HFDI & $(0.080)$ & $(0.075)$ & $(0.086)$ \\
& 0.206 & 0.227 & 0.211 \\
EFDI & $(0.191)$ & $(0.172)$ & $(0.173)$ \\
& $-0.651^{* * *}$ & $-0.541^{* * *}$ & $-0.689^{* * *}$ \\
TFP & $(0.115)$ & $(0.108)$ & $(0.122)$ \\
& & $-0.279^{* * *}$ & $-0.331^{* * *}$ \\
Size & & $(0.041)$ & $(0.038)$ \\
& & & $0.171^{* * *}$ \\
Skill Intensity & & & $(0.036)$ \\
& & & $-0.027^{*}$ \\
Capital Intensity & & & $(0.017)$ \\
& & & -0.030 \\
& & & $(0.019)$ \\
& & & 63,127 \\
\hline
\end{tabular}

Robust standard errors in parentheses

$$
* * * \mathrm{p}<0.01,{ }^{* *} \mathrm{p}<0.05,{ }^{*} \mathrm{p}<0.1
$$

